\title{
Changes in Accounting Conservatism in Pre- and Post- IFRS Adoption in Jordan
}

\author{
Mohammad M. Humeedat \\ Assistant Professor, Department of Accounting and Accounting Information System, Amman University College \\ for Financial Administrative Sciences, Al- Balqa Applied University
}

\begin{abstract}
Studying the changes in accounting conservatism in Pre- and Post- IFRS adoption has received great attention by researchers recently. However, there is a lack of previous studies dealing with this subject for sufficient periods and in the banking sector specifically in Jordan. Therefore, the purpose of this study is to examine the relationship between the adoption of IFRS and the accounting conservatism and then measure the degree of change in the level of conservatism for the period 2000-2008 before applying the standards and 2009-2017after applying it.

After conducting appropriate statistical analysis and testing hypotheses, the results reveal an overall increase in conditional accounting conservatism during the study period and a higher increase following IFRS adoption. Also, the results provide evidence of significant differences in the level of accounting conservatism for the accounting earnings in pre- and post-adoption of IFRS.
\end{abstract}

Keywords: Conservatism, International Financial Reporting Standard (IFRS), Jordanian commercial banks.

DOI: $10.7176 / \mathrm{RJFA} / 10-4-02$

\section{Introduction}

Jordan is one of the first countries to adopt international financial reporting standards in the Middle East. In 1990, the Jordan Association of Certified Public Accountants adopted international accounting standards to be applied by companies in Jordan. However, the adoption of these standards did not constitute a legal obligation for companies due to the lack of binding authority by the Jordan Association of Certified Public Accountants in Jordan. In 1998, the Jordan Securities Commission issued a disclosure directive based on international accounting standards and international auditing standards.

The development of the accounting standards coincided with the development of some new and old accounting concepts, including the concept of accounting conservatism, which arose due to uncertainties surrounding the accounting practice. Generally speaking, conservatism is not considered an accounting assumption but a limitation on accounting measurement and disclosure. The term "accounting conservatism" generally refers to that the accountants must include in their financial reports the lowest possible values of assets and revenues and the highest possible values of expenses and losses; that is, it represents a pessimistic view. This concept is an important feature of generally accepted accounting principles (GAAP), and its use in accounting practice remains a dominant feature. Its importance appears in several areas, the most important of which are its impact on cash flows, where future cash flows are higher in more conservative financial reports (Jain \& Rezaee, 2004), and its relationship with the development of accounting standards.

The increase in accounting conservatism is one of the most important dialectical issues in modern accounting thought, which has been the focus of many accounting studies. Conservatism helps to protect the rights of shareholders, creditors, and other stakeholders in the company. However, there are many criticisms of conservatism as a result of its inconsistency with certain qualitative characteristics of accounting information, such as neutrality, relevance, and faithful representation, particularly in light of the IFRS of fair value concepts (Alqashi, 2008). Many studies have concluded that the shift to IFRS has led to lower levels of earning management and increased levels of accounting conservatism (Hellman, 2008; Latrids \& Rouvolis, 2010). Other studies have showed that the transition to IFRSs resulted in lower levels of accounting conservatism in financial reporting (Karampinis \& Hevas, 2011; Wang et al., 2008). Therefore, the problem of this study is the following main question: "Are there differences in the level of accounting conservatism for accounting earnings in Jordanian commercial banks listed on the Amman Stock Exchange between the subsequent period and the period prior to the mandatory application of IFRS in 2009?

\section{Literature Review and Hypotheses Development}

\subsection{Accounting Conservatism}

Referring to prior literature related to the concept of accounting conservatism, we find that there is no agreed-upon definition of this concept in terms of form, while there is agreement in term of substance. Watts (1993) defined accounting conservatism as a concept in which the lowest values of assets should be taken from among several possible available values and vice versa for liabilities. Basu (1997) stated that conservatism require a higher degree of verification for identifying good news in earnings than bad news. Welker et al. (2004) recognized that financial reports should reflect expected losses more than expected earnings during the financial period. Chung and Wynn 
(2008) stressed that the accounting conservatism leads to reduction in the net asset value of the company to avoid future risks and produce more accurate information to different users. Based on the above definitions, we note that the concept of accounting conservatism reflects a pessimistic view by recognizing the lower accounting values available for the assets and vice versa for liabilities and recognizing expected losses while ignoring expected earnings.

In recent years, many accounting research have tended to study the accounting conservatism in a way that draws attention. Conservatism has affected accounting practice for at least five centuries (Basu, 1997). LaFond and Watts (2008) indicate that conservatism reduces the manager's incentives and ability to manipulate accounting figures and thus reduces information asymmetry. Kravet (2014) argued that conservative accounting practices have reduced management's tendency towards more risky investments.

Most previous studies have divided accounting conservatism into two basic types: conditional conservatism and unconditional (Basu, 1997; Kikuta et al., 2018; Watts, 2003). Kikuta et al. (2018) define conditional conservatism as a practice that records expenses and losses earlier and overstates them when firm value declines due to economic losses compared to profits when firm value improves due to economic benefits. On the other hand, unconditional conservatism is an accounting practice that proactively records expenses before firm value declines due to economic losses. The nature of these two types of conservatism differs significantly, as does their impact on financial reporting. In our current study, we address the first type only, which we measure through the Basu (1997) model.

\subsection{Conservatism in IFRS}

Financial reporting is an important accounting practice that must be performed by companies at the end of each period, which shows the financial position of the company, the result of its activity, its cash flows, its shareholders' rights, and other information suitable for economic decision-makers of different types, which helps them to make their decisions. (AL-Shammari et al., 2008).

Several IFRS have addressed the concept of accounting conservatism indirectly, which is an indication of the importance of this concept. Examples include IFRS no. 2 inventory, paragraph 9, which indicates that the value of inventories is evaluated at the lower cost or net realizable value. Additionally, paragraph 28 of the same standard stipulates that it may not be possible to recover the cost of the inventory if it becomes damaged or has become fully or partially depleted or the selling price has decreased. There are also other places mentioned in the IFRS that indicate the adoption of the concept of conservatism, including what is stated in paragraphs 26 and 32 of standard no. 11 and in paragraphs 30 and 31 of standard no. 16.

In reviewing the prior studies, we note that a large number of these studies focused on a research aspect that dealt with the effect of IFRS adoption on accounting conservatism. Fullana et al. (2017) indicated that the adoption of IFRS did not have any effect on the unconditional accounting conservatism in Spanish listed companies.

Arabiat and Khamees (2016) found that the level of decline in conditional conservatism after the applying of (IAS/IFRS) is more noticeable in the companies that report intangible assets and the impairment of goodwill in their financial position. Also, André et al. (2015) confirmed a decline in conditional conservatism in postmandatory IFRS adoption, especially in countries which have low audit environment and weak enforcement of compliance. Zeghal and Lahmar (2016) confirmed a significant reduction of accounting conservatism in the IFRS adoption period. On the other hand, earlier studies employ timely loss recognition as a proxy for conservatism. Barth et al. (2008) show that voluntary IAS adoption is associated with more timely loss recognition, and Chua et al.'s (2012) study in Australia, where IFRS adoption is mandatory, reports similar results. Zhang (2011) found the existence of conditional conservatism for both pre- and post-adoption of IFRS, and it is increased after the adoption of IFRS in New Zealand. Balsari et al. (2010) show that IFRS adoption has increased both the timeliness and earnings conservatism (asymmetric timeliness). Finally, Kikuta et al. (2018) examined whether there is a difference in the degree of conditional and unconditional conservatism between firms that adopt IFRS and those that use Japanese generally accepted accounting principles (J-GAAP), concluding that conditional conservatism is larger for IFRS adopters than for J-GAAP.

According to the above-mentioned studies, the issue of the effect of IFRS adoption on accounting conservatism is still a wide and renewed research field in terms of subject and scope. Because of the spread of application of IFRS in most countries, including Jordan, and because the development of these standards is ongoing and has not stopped at a certain point. Our study is an extension of previous studies. We measure the level of earnings conservatism before and after the adoption of IFRS and then measure the differences in the level of earnings conservatism in all Jordanian commercial banks after applying IFRS.

Based on the above, the hypotheses of the study can be formulated as follows:

H01: Jordanian commercial banks do not adopt the concept of accounting conservatism for accounting earnings in the pre-IFRS adoption period (2000-2008).

H02: Jordanian commercial banks do not adopt the concept of accounting conservatism for accounting earnings in the post-IFRS adoption period (2009-2017). 
H03: There are no statistically significant differences in the level of accounting conservatism for accounting earnings in Jordanian commercial banks between pre-and post-adoption of IFRS.

\section{Methodology}

\subsection{Sample Selection}

The study population consists of all the commercial banks listed on the Amman Stock Exchange, which are equal to 13 banks according to the Jordanian company's guide of 2018. The sample of the study included all commercial banks.

\subsection{Variable Measurement and Research Model}

Many models were used in previous studies to measure accounting conservatism. The most important is the Basu (1997) model. Based on this model, conservatism results in earnings that are expected to be more strongly related to concurrent negative unexpected returns, which proxy for bad news, than positive unexpected returns, which proxy for good news.

$$
\mathrm{X}_{\mathrm{i}} \mathrm{t} / \mathrm{P}_{\mathrm{i}} \mathrm{t}-1=\alpha+\beta_{1} \mathrm{R}_{\mathrm{i}} \mathrm{t}+\beta_{2} \mathrm{DR}_{\mathrm{i}} \mathrm{t}+\beta_{3}\left(\mathrm{R}_{\mathrm{i}}{ }^{*} \mathrm{DR} \mathrm{R}_{\mathrm{i}} \mathrm{t}\right)
$$

$\mathrm{X}_{\mathrm{i}} \mathrm{t} / \mathrm{P}_{\mathrm{i}} \mathrm{t}-1$ : $\mathrm{X}_{\mathrm{i}} \mathrm{t}$ is the earnings per share for firm $\mathrm{i}$ in fiscal year $\mathrm{t}$; $\mathrm{P}_{\mathrm{i}} \mathrm{t}$ is the price per share at the beginning of the fiscal year.

$\left(\mathrm{R}_{\mathrm{i}} \mathrm{t}\right)$ is the return on firm $\mathrm{i}$ in year $\mathrm{t}$.

$\left(\mathrm{DR}_{\mathrm{i}} \mathrm{t}\right)$ is a dummy variable: $=1$ if $\mathrm{Rit}<0,=0$ otherwise.

$\left(\mathrm{DR}_{\mathrm{i}} \mathrm{t} \times \mathrm{R}_{\mathrm{i}} \mathrm{t}\right)$ is the multiplication of the binary variable in return.

In this study, the Basu (1997) model was developed with the introduction of the IFRS variable. Consequently, the Basu model used in this study is as follows:

$\mathrm{X}_{\mathrm{it}} / \mathrm{P}_{\mathrm{it}-1}=\alpha+\beta_{1} \mathrm{R}_{\mathrm{it}}+\beta_{2} \mathrm{DR}_{\mathrm{it}}+\beta_{3}\left(\mathrm{R}_{\mathrm{it}} * \mathrm{DR}_{\mathrm{it}}\right)+\beta_{4} \mathrm{IFRS}_{\mathrm{it}-1}+\beta_{5} \mathrm{IFRS}_{\mathrm{it}-1} * \mathrm{R}_{\mathrm{it}}+\beta_{6} \mathrm{IFRS}_{\mathrm{it}-1} * \mathrm{DR}_{\mathrm{it}}+\beta_{7} \mathrm{IFRS}_{\mathrm{it}-1} * \mathrm{R}_{\mathrm{it}} * \mathrm{DR}_{\mathrm{it}}+$ Uit

The revised Basu (1997) model was used to measure the extent to which the conservatism level generally differed after the first-time application of IFRS in 2009 compared to the conservatism level prior to the adoption of IFRS before 2009. The IFRS variable is considered an indicator variable that equals 1 in the post-IFRS adoption period and 0 otherwise.

Market returns (Rit) are important variables in the previous equation, and this variable was measured by the following equation:

$$
\left[\left(P_{i t}-P_{i t-1}+d_{i t}\right) / P_{i t-1}\right]
$$

(Pit): Closing price for the firm I in year $\mathrm{t}$.

(Pit-1): Closing price for the firm I in year t-1.

(dit): Dividends per share.

The binary measurement of news is used here. If the return signal at the end of the period $(\mathrm{t})$ is negative, the news received by the market during the period is considered to be bad news, in which case the variable is given a value of 1 . If the return signal is positive or the return is 0 at the end of the period, it assumes that the news received by the market as a whole is positive and gives the variable a value of 0 .

\section{Empirical Results}

This section provides the findings and interpretations that resulted from various statistical methods used in data analyses.

\subsection{Descriptive Statistics}

The descriptive statistics for all study variables are presented in Table 1. It shows that the mean of the variables carries positive values with a difference in earnings per share values during the study period because the value of the standard deviation of this variable is high.

\begin{tabular}{|l|c|c|c|c|}
\hline \multicolumn{5}{|c|}{ Table 1. } \\
\hline \multicolumn{7}{|c|}{ Variable } & Mean & Maximum Value & Minimum Value & Standard Deviation \\
\hline EPS & 27.74 & 87.97 & 7.66 & 34.34 \\
\hline $\mathbf{R}_{\mathbf{i t}}$ & 0.25 & 0.35 & 0.03 & 0.13 \\
\hline
\end{tabular}

\subsection{Normal Distribution}

One of the important conditions in a general linear model (GLM) is that the values of the observations follow the normal distribution. If this condition is not met, the data are processed using the natural logarithm or square root and other procedures. It was verified by using the Jarque-Bera test to ensure that the study data follow the normal distribution. The results were as follows: 


\begin{tabular}{|c|c|c|}
\hline \multicolumn{3}{|c|}{$\begin{array}{c}\text { Table 2. } \\
\text { Jarque-Bera test }\end{array}$} \\
\hline Variable & Jarque-Bera & 0.71 \\
\hline EPS (Xit) & 1.55 & 0.70 \\
\hline Price (Pit-1) & 0.69 & 0.50 \\
\hline Price (Pit) & 1.35 & 0.75 \\
\hline Return (Rit) & 0.57 & -value \\
\hline
\end{tabular}

Table 2 shows that the P-value of all variables is greater than 0.05 , indicating that all the variables of the study follow the normal distribution (Guajarati, 2003).

\subsection{Multicollinearity}

The strength of the GLM is based primarily on the independence of each independent variable to ensure that the collinearity diagnostics test was used by calculating the variance inflation factor (VIF) among the study variables. Table 3 shows that there is no linear correlation problem in the study model because the VIF for all variables is less than 10 (Gujarati, 2003).

\begin{tabular}{|c|c|}
\hline \multicolumn{2}{|c|}{ Table 3. } \\
VIF test \\
\hline Variable & VIF \\
\hline DR & 5.26 \\
\hline Return (Rit) & 3.12 \\
\hline Rit*DRit & 5.35 \\
\hline
\end{tabular}

\subsection{Autocorrelation}

The autocorrelation problem appears in the model if contiguous observations are interrelated, which will affect the validity of the model. To verify this, the D-W Durbin test was used, which equals 1.920 . It is close to the number 2, which means that the autocorrelation problem is not present in the regression model (Gujarati, 2003).

\subsection{Testing the Hypotheses}

The basic Basu model is one of the most common models for measuring the level of accounting conservatism through the following regression equation:

$$
\mathrm{X}_{\mathrm{i}} \mathrm{t} / \mathrm{P}_{\mathrm{i}} \mathrm{t}-1=\alpha+\beta_{1} \mathrm{R}_{\mathrm{i}} \mathrm{t}+\beta_{2} \mathrm{DR} \mathrm{i} \mathrm{t}+\beta_{3}\left(\mathrm{R}_{\mathrm{i}} \mathrm{t} * \mathrm{DR}_{\mathrm{i}} \mathrm{t}\right)
$$

When the above equation was tested on two sub-samples, between the period prior to the mandatory application of IFRS (2000-2008) and the subsequent period of mandatory implementation of IFRS (2009-2017), the additional response to bad news compared with good news was measured through the regression coefficient $\beta 3$ of the variable $R * D R$. In conservative reports, the response factor $\beta 3$ of the variable $R * D R$ is expected to be positive, and for the coefficients $\beta 2+\beta 3 / \beta 2$, it is expected to be greater than 1 . This index measures the earnings response to bad news compared to its response to good news. If the amount of the index is greater than 1 indicates that bad news is recognized faster than good news (Basu, 1997).

\subsubsection{Testing the First Hypothesis}

Table 4 shows the statistical results that measure the level of accounting conservatism for accounting earnings in the pre-IFRS adoption period (2000-2008).

\begin{tabular}{|c|c|c|c|}
\hline \multicolumn{5}{|c|}{ Table 4 } \\
\hline Rear & \multicolumn{3}{|c|}{ 2001-2008 } \\
\hline Variables & Coef & Sig. & T \\
\hline Intercept & 0.32 & 0.746 & 0.34 \\
\hline $\mathrm{R}$ & -0.041 & 0.550 & -0.61 \\
\hline $\mathrm{DR}$ & -0.44 & 0.675 & -0.43 \\
\hline $\mathrm{R} \times \mathrm{DR}$ & 0.29 & 0.116 & 1.62 \\
\hline $\mathrm{R}^{2}$ & \multicolumn{3}{|c|}{$10.9 \%$} \\
\hline $\mathrm{Adj}-\mathrm{R}^{2}$ & \multicolumn{3}{|c|}{$4.2 \%$} \\
\hline$\left(\beta_{2}+\beta_{3}\right) / \beta_{2}$ & \multicolumn{3}{|c|}{0.35} \\
\hline
\end{tabular}

The interactive slope coefficient $\beta_{3}$ is significant and positive (0.29). This result can be confirmed by the value of the coefficient $\beta 2+\beta 3 / \beta 2$, which is 0.35 , meaning that the earnings are about three times as sensitive to negative returns as they are to positive returns. Therefore, Jordanian commercial banks adopted the concept of accounting conservatism for the period 2000-2008, but at a low level, because the value of the previous index was less than 1 . Thus, the first hypothesis is rejected. 


\subsubsection{Testing the Second Hypothesis}

Table 5 shows the statistical results that measure the level of accounting conservatism for accounting earnings in the post-IFRS adoption period (2009-2017).

\begin{tabular}{|c|c|c|c|}
\hline \multicolumn{4}{|c|}{$\begin{array}{c}\text { Table } 5 \\
\text { Regression Results post-IFRS adoption }\end{array}$} \\
\hline Year & \multicolumn{3}{|c|}{$2009-2016$} \\
\hline Variables & Coef & Sig & $\mathrm{T}$ \\
\hline Intercept & 0.56 & 0.851 & 0.19 \\
\hline $\mathrm{R}$ & -0.072 & 0.705 & -0.38 \\
\hline DR & 0.84 & 0.791 & 0.28 \\
\hline $\mathrm{R} \times \mathrm{DR}$ & 0.86 & 0.030 & 2.28 \\
\hline $\mathrm{R}^{2}$ & \multicolumn{3}{|c|}{$18.2 \%$} \\
\hline Adj-R ${ }^{2}$ & \multicolumn{3}{|c|}{$11.4 \%$} \\
\hline$\left(\beta_{2}+\beta_{3}\right) / \beta_{2}$ & \multicolumn{3}{|c|}{2.02} \\
\hline
\end{tabular}

The interactive slope coefficient $\beta_{3}$ is significant and positive (0.86), which indicates significant improvement in the level of accounting conservatism in the period following the adoption of IFRS. This result can be confirmed by the value of the coefficient $\beta 2+\beta 3$ / $\beta 2$, which is 2.02 , meaning that the earnings are about 20 times as sensitive to negative returns as to positive returns. In other words, bad news is recognized faster than good news, and thus the second hypothesis is rejected.

The main reason for the increase in accounting conservatism is the tendency of IFRS to apply the concept of fair value instead of the historical cost concept, which is the best measure that reflects the market value of the items of financial reports in an efficient and active market. As the Jordanian market does not enjoy this feature, more personal misjudgments occur, resulting in increased accounting conservatism.

\subsubsection{Testing the Third Hypothesis}

In order to test the third hypothesis, the basic Basu model was applied first, and then the modified model was applied by introducing an indicator variable that represents the IFRS. Table 6 shows the calculations of the fundamental differences of factor $\beta 3$ of the variable $\mathrm{R} \times \mathrm{DR}$ for the two periods.

\begin{tabular}{|c|c|c|c|c|c|}
\hline \multicolumn{6}{|c|}{$\begin{array}{c}\text { Table } 6 \\
\text { Differences of factor }(\beta 3) \text { of the variable }(\mathrm{R} \times \mathrm{DR}) \text { for period's pre and } \\
\text { Post-adoption of IFRS for basic Basu model. }\end{array}$} \\
\hline & & Sum of Squares & Mean of Squares & $\mathrm{F}$ & Sig. \\
\hline \multirow[t]{3}{*}{$\mathrm{R} \times \mathrm{DR}$} & Between Groups & 0.025 & 0.025 & 3.81 & 0.055 \\
\hline & Within Groups & 0.661 & 0.007 & & \\
\hline & Total & 0.686 & & & \\
\hline
\end{tabular}

In order to test the significance of the fundamental statistical differences of the regression coefficients for the two periods, the F-test of the variable $\mathrm{R} * \mathrm{DR}$ was used. We note that the value of $\mathrm{F}$ for the variable is equal to 3.81 , with a P-value equal to 0.055 . This indicates that there were no significant differences in the level of accounting conservatism during the periods of study after applying the basic Basu model.

Table 7 shows the calculations of the fundamental differences of factor $\beta 3$ of the variable $\mathrm{R} \times \mathrm{DR} \times \mathrm{IFRS}$ for the periods of pre- and post-adoption of IFRS.

\begin{tabular}{|c|c|c|c|c|c|}
\hline & $\begin{array}{r}\text { Differences of fa } \\
\text { Pre and po }\end{array}$ & $\begin{array}{c}\text { Table } 7 \\
\text { 3) of the variable } \\
\text { otion of IFRS for }\end{array}$ & $\begin{array}{l}\mathrm{R} \times \mathrm{IFRS} \text { ) for peric } \\
\text { ed Basu model. }\end{array}$ & & \\
\hline & & Sum of Squares & Mean of Squares & $\mathrm{F}$ & Sig. \\
\hline $\mathrm{R} \times \mathrm{DR} \times \mathrm{IFRS}$ & Between Groups & 2.156 & 2.156 & 4.35 & 0.041 \\
\hline & Within Groups & 41.210 & 0.498 & & \\
\hline & Total & 43.366 & & & \\
\hline
\end{tabular}

Note that the value of $\mathrm{F}$ for the variable $\mathrm{R} * \mathrm{DR} * \mathrm{IFRS}$ is 4.35 and has a significant statistical value. The $\mathrm{P}$ value of this variable is 0.041 , indicating that the level of accounting conservatism increased during the subsequent period of IFRS adoption. Therefore, the null hypothesis is rejected, because there are significant differences in the level of accounting conservatism for the accounting earnings in Jordanian commercial banks between pre- and post-adoption of IFRS. This result is consistent with the results of many previous studies (e.g. Balsari et al., 2010; Zhang, 2011).

\section{Conclusion}

The empirical results provide evidence that Jordanian commercial banks adopted the concept of accounting conservatism for the accounting earnings during the study period, which was higher in the post-IFRS adoption period (2009-2017). Furthermore, the results provide evidence of significant differences in the levels of accounting 
conservatism for the accounting earnings in Jordanian commercial banks between pre- and post-adoption of IFRS.

\section{References}

Alqashi, T. (2008). The adopted policy in classifying investments in securities as per IAS 39 in Jordanian Public Companies, Arab Journal of Administration, 28(2), 85-110.

Al-Shammari, B., Brown, B. \& Tarca, A. (2008). An investigation of compliance with international accounting standards in the Gulf Co-operation Council member states: An empirical study. The International Journal of Accounting, 43, 425-447.

André, P., Filip, A. \& Paugam, L. (2015). The effect of mandatory IFRS adoption on conditional conservatism in Europe. Journal of Business Finance \& Accounting, 42(3-4), 482-514.

Arabiat, O. \& Khamees, B. (2016). The impact of mandatory IFRS adoption on conditional conservatism in Jordan. Dirasat, Administrative Sciences, Jordan, 43(1), 275-286.

Balsari, C., Ozkan, S. \& Durak, M. (2010). Earnings conservatism in Pre- and Post- IFRS periods in Turkey: panel data evidence on the firm specific factors. Journal of Accounting and Management Information Systems, 9(3), 403-421.

Barth, M., Landsman, W., and Lang, M. (2008). "International Accounting Standards and Accounting Quality." Journal of Accounting Research 46(3), 467-498.

Basu, S. (1997). The conservatism principle and the asymmetric timeliness of earnings. Journal of Accounting \& Economics, 24, 3-37.

Chua, Y., Cheong, C \& Gould, G. (2012). The Impact of mandatory IFRS adoption on accounting quality: evidence from Australia. Journal of International Accounting Research, 11(1), 119-146.

Chung, H. \& Wynn, J. (2008). Managerial legal liability coverage and conservatism. Journal of Accounting and Economics, 46(1), 135-153.

Fullana, O., Gonzalez-Sanchez, M. \& Toscano, D. (2017). The effects of IFRS adoption on the unconditional conservatism of Spanish listed companies. https://papers.ssrn.com/sol3/papers.cfm?abstract id=2926896.

Gujarati, D.( 2003). Basic Econometrics, (4th edition) New York: McGraw-Hill Book, Com, p.147.

Hellman, N. (2008). Accounting conservatism under IFRS. Accounting in Europe, 5(2), 71-100.

Jain, P. \& Rezaee, Z. (2004). The Sarbanes-Oxley act of 2002 and accounting conservatism. Working Paper Series, available at: www.ssrn.com.

Kikuta, S., Shimamoto, K. and Takeda, F. (2018). Is IFRS conditionally or unconditionally more conservative than local GAAP? Evidence from Japan. AAA Annual Meeting paper. Available at SSRN: https://ssrn.com/abstract=3185615

Kravet, T. (2014). Accounting conservatism and managerial risk-taking: Corporate acquisitions. Journal of Accounting and Economics, 57(2-3), 218-240.

LaFond ,R. \& Watts L. (2008). The information role of conservatism. Accounting Review, 83(2), 447-478.

Latridis, G. \& Rouvolis, S. (2010). The post-adoption effects of the implementation of international financial reporting standards in Greece. Journal of International Accounting, Auditing and Taxation, 19, 55-65.

Wang, X., Young, D. \& Zhuang, Z. (2008). The effects of mandatory adoption of International Financial Reporting Standards on information environments. Unpublished paper, The Chinese University of Hong Kong.

Watts, L. (1993). A Proposal for research on conservatism, Financial Research and Policy. Working Paper Series, University of Rochester.

Watts, L. (2003). Conservatism in accounting. Part I: explanations and implications, Part II: evidence and research opportunities. Accounting Horizons, 17(3), 207-221.

Welker M., Thornton D. \& Pae J. (2004). The link between earnings conservatism and balance sheet conservatism. Contemporary Accounting Research, 22(3), 693-717.

Zeghal, D and Lahmar, Z. (2016). The impact of IFRS adoption on accounting conservatism in the European Union. International Journal of Accounting and Financial Reporting, 6(1), 127-160.

Zhang, J. (2011). The effect of IFRS adoption on accounting conservatism -New Zealand perspective, Unpublished Master Dissertation, Auckland University of Technology. 